\title{
NGO THI NHAM: THE AUTHOR OF THE RELIGION CONFUCIAN IN THE VIETNAMESE MEDIEVAL LITERATURE
}

\author{
Le Van $\operatorname{Tan}^{1}$ and Nguyen Thị Huong ${ }^{2}$ \\ ${ }^{1,2}$ Graduate Academy of Social Science, Vietnam Academy of Social Science \\ DOI: 10.46609/IJSSER.2021.v06i01.023 URL: https://doi.org/10.46609/IJSSER.2021.v06i01.023
}

\begin{abstract}
Ngo Thi Nham was a great talent in diplomacy, politics, military, literature, and he made many important contributions to the Le Dynasty - Trịnh and Tay Son. These characteristics have formed the kind of religious director in medieval literature. Although he composed in any topic, we all see the most obvious point is the image of a soldier who always wants to bring his energy to serve the people and serve the country.
\end{abstract}

Keywords: Ngo Thi Nham; type of author; the author of the Confucian; the Confucian religion; medieval literature.

\section{Open the beginning}

Ngo Thi Nham (1746-183), self-Hy Doan, nicknamed Dat Hien, who belonged to Ta Thanh Oai village, now belongs to Thanh Tri district, Hanoi city. He passed the first prize in 1768, then went to Tam Tam in 1775, working on the Le-Trinh and Tay Son dynasties. With a flexible concept of the museum, Ngo Thi Nham pursued and persevered in the path of the knight's practice in times of turmoil. With nearly 600 poems left, he deserves to be a model of a typical religious director, a great literary author in the second half of the eighteenth century in particular, of medieval Vietnamese literature in general. He made great political and military contributions to the Le-Trinh dynasty, especially Tay Son. In any situation or situation, he always maintains the ideal of serving the people, serving the country of a true intellectual. In the field of poetry, Ngo Thi Nham also left a huge volume of writing with content rich, condensed, rich in value, honest and close to the reader.

\section{Content of research and discussion}

\subsection{The way of action of the author of the Confucian in the time of turmoil}

In the medieval period, the intellectuals receiving Confucian studies wanted to bring their talents to do the things devoted to the main government and communal rule. But also for many reasons, 


\section{International Journal of Social Science and Economic Research}

ISSN: $2455-8834$

Volume:06, Issue:01 "January 2021"

many grape houses did not fulfill their wishes. We think that when we look at the grape houses and their contributions to history, we need to be recognized in many different ways.

In 1778, he was appointed as the Director of Kinh Bac and Thai Nguyen, then went through positions such as the East of the Branding Offices, the Workshop of the Workshop, Huu Thi Lang Bo Cong. At this time, he began to be famous for his talent in literature and poetry in the group of Bac Ha soldiers at that time.

During the period of mandarins under the Trinh and Ngo Thi Nham lords, they devoted themselves to the hard work and hardship to be able to do well their duties, which is also the spirit of self-responsibility of the Confucianists. He always cares about the life of the people, not hesitating to be disappointed by the Lord to report directly to the eyes and ears about the situation of the people or the evils in the contemporary government. In the Hai Duong Hearing of the revelation, he once wrote: "The land in the Southeast belongs to the best kind in the country, the river is surrounded by a band of hats, belts, and fertile marshes, despite droughts and floods. wading, not having to worry ... Now that wild fields, left unattended, but those who manage to rely on old books to collect taxes, farmers have to borrow other jobs to get paddy to pay . The people's misery of suffering is in that place"[1]. Ngo Thi Nham's contributions as the Governor of Thai Nguyen were satisfied with the Trinh lord, but in the later period, the court was confused and forced him to flee to his hometown of his first wife in Am Le Trach, Doi Trach commune. , Son Son Nam (now belongs to Vu Thu district, Thai Binh province).

In 1788, Nguyen Hue went to the North for the second time and went down to the order of "gentle bridge" to serve the construction of the country. Ngo Thi Nham and some other Bac Ha relatives such as Phan Huy Ich, Bui Duong Lich, and Ninh Ton ... took turns to visit and open their eyes to Tay Son.

Ngo Thi Nham, a mandarin of Tay Son, passed the medieval conception of a medieval house. Enthusiastic with the main court, with his people was continued and at a new level. During this time, Ngo Thi Nham was especially trusted by King Quang Trung. At first, he was assigned to hold the position of Huu lang of Cong dynasty, depicting Tinh Phai, and with Vo Van Uoc considered all martial artists of the Le Dynasty. In October 1788, Ton Si Nghi brought 29 thousand Qing troops to invade our country, Ngo Thi Nham and his generals, including Ngo Van So, discussing and taking over the enemy. The most important dedication at this time of Ngo Thi Nham is "Tam Diep", retired to Tam Diep while preserving the force, while keeping the critical position waiting for the army, making the Thanh army hostility. This book of Ngo Thi Nham was praised by King Quang Trung himself, and the "Tam Diep chess game" is considered by history to be one of the most important factors determining the glorious victory of the Tay Son spring. In 1789, Ngo Thi Nham was entrusted with more responsibilities by the Tay Son Dynasty. In any 


\section{International Journal of Social Science and Economic Research}

ISSN: $2455-8834$

Volume:06, Issue:01 "January 2021"

position, he was wholeheartedly devoted to the work, taking care of the people for the country. After the death of King Quang Trung, the reign of the political court, internal divisions, the Nguyen Dynasty was replaced, the Tay Son dynasties were harmed and Ngo Thi Nham was not an exception. Ngo Thi Nham persevered in the path of the martyrs during the rebellion, no matter what position and situation he was in, he put national interests first. Ngo Thi Nham devoted himself to serving the Tay Son dynasty, and with his talent, he made important contributions to the cause of building and defending the country. Ngo Thi Nham's contributions to the Tay Son dynasty have been confirmed by researchers in many fields: politics, military, diplomacy and economy.

\subsection{The idea of incarnation of the Confucian}

In times of turmoil, some grape houses were secluded (appearing) to express their attitude to the times, others chose to enter the world to serve the country, Ngo Thi Nham belonged to the second motif. The poetic rhymes (using poetry to speak) make up a large part of Ngo Thi Nham's poetic career. It is the head of an exemplary religious monk with a heart that is always directed to communal rule, the people. The lice that the author has absorbed from Confucian thought. He always determined, mindful of the role of self-responsibility of the Confucianist before life. Encountered in Ngo Thi Nham's poem, a human being is always ready to give up his body for meaning, without managing hardships: "Going to fight the enemy does not mind long separation. the teacher, is the position of my child / Please bring sweet rain to irrigate the mountainous people"(through Nguyet Duc river boat).

During his stay in his wife's home village in Doi Trach commune, Son Nam town (now Vu Thu district, Thai Binh province), he was steadfast and steadfast, looking forward to a bright tomorrow, the day when he would meet the intelligent army. So that he could bring his talents to serve in the main court, serving the people. The poem written as if he were to motivate himself and encourage him to try: "Learning nothing more than trying/ One need" in hundred, ten "need" in thousand / Thai Mountain, Cao Cao Mountain heavenly, should add another basket / Flower horse, horse to catch up with the sun must also whip" (Write "Free son").

When he was joined by the main court and respected, Ngo Thi Nham wrote many poems of praise to King Quang Trung Nguyen Hue, praising the Tay Son dynasty. The poem was written excitedly with his belief, his optimism about a new era will be opened: "A bunch of gliding dragons, support the Jade Emperor / Fly in the air in the sky / Cloudy ray scanning blind, open the fall color / See the old sun in the sky like that "(Big wind).

A series of poems he wrote to send to his younger brother, Hoc Tu, his uncle or his cousin Tran in Van Canh, donated to the lieutenant Tran Van Ky ... and many other poems written when Ngo 


\section{International Journal of Social Science and Economic Research}

ISSN: $2455-8834$

Volume:06, Issue:01 "January 2021"

Thi Nham went back to porcelain. From Yen to Phu Xuan continues to show affection as well as admiration for the new opportunity of the country: "Like the spring wind, like the winter sun / Sympathy, still forever and dear / Uy Strictly suspicious like the Ky River Tree / the Steady Heart like the cold-season pine tree / Red Belt, it is necessary to have the elders / Take the hat, always remember his religion / Close to the Military music under the high clouds on the door defect / splash of Thai Thanh bell brought to the military business "(Giving the central mandarin is Ky Thien Hau).

On the way to the South to take office, he wrote optimistic, expansive poems, believing in the new dynasty that would bring the country peace, for the people to be warm: "First time going to the South to Nghe An / Each landscape is a dream, a wonder / sand dunes want to adore the sea / a stone of overlap, soaring to the Ngan River / Land with meritorious dignity, beautiful riverside / magnificent births, stars Around the road / Mai mai memorizes the famous villages / Clearly the heroes recorded in history books "(On Nghe An street).

Through the poetic rhetoric, Ngo Thi Nham has shown to be a Confucianist with an incarnate mind, always ready to bring his effort and talent to serve the people and serve the country. His poems, expressing the heroism of a typical martyr in the time of rebellion.

\subsection{Romance with the homeland and the country of the Confucian}

Ngo Thi Nham's porcelain poetry contributed to the poetic line of Vietnamese medieval literature both in content and art. Not only is the recording of what the eyes see, the poems of his mission also show the author's affection for his homeland, including the heavy thoughts about the destiny of the country.

One of the most recognizable things in his poem in this topic is his pride of immaturity, his homeland, his majestic feats of his father's old days: "... The sword of the gods keeps the mark on the general stone. Minh / Smoke of the Devil locked the temple of Han Dynasty / After the North of South opened the gate / The guide for the porcelain from Yen Kinh to ... The path appeared from the green grass / field of the rice field as exploited from the cloud very beautiful / very wondrous is the sky a strip / In the constellation of the planet at the middle, bright and brilliant star Dau Sao Thai (Along Lang Son road).

He made a lot of articles of Chinese historical figures such as Zhuge Liang, Jia Yi, Van Thien Tuong, To Dong Pha... to pay homage to the famous ancient sages of talent and contributions. contributed to the main tide. Hidden after the poem is his mind with the main court, the heart of the poet always turns to his hometown: "Dragon man" turned, then "dragon god" appears / Rock mountain towering by the river, looking at Han Trung / North Wei, intending to confess in battle / Swallow Dong Ngo, angry people blowing rumors / The leg of the cauldron is not enough to 


\section{International Journal of Social Science and Economic Research}

ISSN: $2455-8834$

Volume:06, Issue:01 "January 2021"

compete with the blue sky / The heart still wants the high-altitude temple in the place of the dome / Cypress pine like waving the slanted days / The water flow collected in Hanh Duong illuminates her heart" (Gia Cat Vu Hau Temple).

The author honestly records when witnessing the tranquility of human land, idle, relaxed, people have a warm life, verses express the desire to see their own people average, warm: "Nam Ninh continues to call" Little Nanjing"/ The character full of flowers full of town / The door of the road, the sun screen / Radio dumbbells on the river, lights like stars ... Good life where there is no work in the road / Birds dance on the chairs, birds on the porch (Write sightings in Nanning). As a nature lover, enjoying the beauty that nature gives to people, the scenery where he went through was redrawn through beautiful and bright poems: "A mountain of a river in turn welcomes / The mountain, the water is clear and clear / The cloud is light, the autumn is August / The cold fog is cold, the middle of the night is the third time" (Autumn is dropping the boat on the Ly River).

Image of Tuong River: "Looking out at the vast Thanh Thao Lake, the waves are calm and the wind is calm, the water surface is flat as the projection / The mountain is dim and low, but there is a mountain / Ben far away, small and small seemingly see nothing"(The morning away from Tuong river).

During the time of traveling as well as returning and staying in China, there were times when Ngo Thi Nham felt very tired but soon after having a million command, he tried and encouraged himself. I pass the situation to serve the country. The change of weather, climate, water and thousands of miles of miles also made him sick. It was an easy time for people to feel frustrated, but with the extraordinary will and energy, Ngo Thi Nham took the country, took the king's trust to maintain the spirit, to be the fulcrum for the journey Process: "... Wherever there is a river of blessing/ Now it is necessary to be soaked with grace and keep / Stay faithful, confident that you are sick / Not worry but not to be spiritually excited).

Automate yourself when you are sick: "This humble body has devoted to the water from then on". The day of the night of the day of the troublesome and troubling day in the misery of being often wise / abstinence, that frugality is a medicine to keep Health"(Narrative when ill).

Ngo Thi Nham's porcelain poetry reflects his true self, a person who is always in pain at the time, loves his homeland, and is touched by the beauty of nature. This topic of his work also contributes to the flow of medieval literature and contributes to the appearance of a type of vine house in the history of literature.

\subsection{The philosophy of idle letters of the Confucian}




\section{International Journal of Social Science and Economic Research}

ISSN: $2455-8834$

Volume:06, Issue:01 "January 2021"

We believe that the inspiration about leisure or leisure is the most interesting meeting point of three types of grape house authors, including the author of Zen master in medieval Vietnamese literature [7, p. 11-18]. With Ngo Thi Nham, the inspiration about idle appearance in most of his poems, including poetry, was the time when he directed his heart to nature, traveling with the wind and clouds, the heart was relaxed after cover all the official offices, official documents: "Autumn colors, yellow flowers, a day of freezing / walking in front of the temple on the river / High floor on the water side, small shadow of the bell / On the clean road to receive the morning sun, gently sand ... (Walking in the sun on the temple by the river).

During the refuge in his wife's village (Thai Binh), the inspiration of idle words helped the poet to preserve the highness of a monk's temperament, helping him to nurture the spirit of waiting for the opportunity to continue. Continue to help people help the country. One visit to Van Dong Street, Ngo Thi Nham has portrayed a peaceful and peaceful natural and daily life of the people: "Light boat, knocking on the paddle to Van Dong / Muoi huong cool breeze with us as a friend / Bai dau, the birds change to back and forth / Giang hamlet, the tree stops to pick up / Six to seven drunken people go on the board / Five young buffalo players play the game / In this There is a street letter under the shade of green willow / On the lamp sitting opposite the table to Korea, Van Dong... "(Van Dong Letter Visit).During the free time Ngo Thi Nham recounted her desire to be hidden, staying away from the customary to be relaxed. In fact, for him, it was only that wish and desire that only appeared in a certain situation but through poetry, we felt inspired by meditation: "Place of inn, at leisure. closing day / Hesitating the poems / Good things at home based on the return letter / The anxiety of the body, knowing the fortune-telling of the grass / The door of the house is like the sea, the legs are low / Landscape the house is as cold as ice, only my heart is good / The white hair of the snow race with apricot blossom / Knowing when to leave the horse back to Hoa Son (say my mind when I am free).

The feeling of leisurely also came to him when he was going to the Qing Dynasty to go to the Qing Dynasty: "The magic of the sky and the sky says how fast / thousands of beautiful images in the afternoon / The high of the yellow mountain, the low color of the sky / On the left side of the water, on the right side of the red / European diving fish like the head of the raptor / Bird on the fluttering wing on the top of the tree / There is also a clearer taste / The bell of the temple is ringing in pine forest (See the afternoon on Le Giang river).

Many times the meditation landscape returns in his poem: "Burning knuckles, flaps drifting five years / This autumn comes to Zen at the village temple/ Chrysanthemum has just hatched a golden splashed armor / Leaf shy, watching again, was sharp smelling Zen / The past was considered a dream Nam Kha / The old me was still charming debt Truc long / Linh am serene, spiritual light / When cool into the pond, a clear water" (At the end, I went to the temple to meditate). 


\section{International Journal of Social Science and Economic Research}

ISSN: $2455-8834$

Volume:06, Issue:01 "January 2021"

With the inspiration towards the meditation of color in many passages of the bumpy, sad and confusing practice path, easy to understand about Ngo Thi Nham's actions and actions at the end of life: establishing a monastery Truc Lam at home wrote "Truc Lam tong nguyen thanh", initiated the pagoda to allow the villagers to have a place to cultivate, to enter a study group to discuss about Zen (Ngo Thi Hoang, Vu Trinh, Nguyen Dang So). What makes Ngo Thi Nham unique is that he always stands at the point of view of a zealous guru when he sees Buddhism. He also proved to be deeply aware of the many problems of Zen Buddhism, but Ngo Thi Nham was not yet the "enlightened" person of Zen because all the energy he had for the people and the country. The meditative poems show that in Ngo Thi Nham, there is an interweaving kind of religious vineyard and reclusive grape house, this is an interesting case of medieval literature.

\section{Conclusion}

Ngo Thi Nham's compositions are examples of his political and ups and downs. No matter what position he was, he brought all his education to help people help the country. Ngo Thi Nham's thoughts and writings contribute to the formation of the characteristics of the religion Confucian in the chaos.

\section{References}

1. Cao Xuan Huy, Thach Can (Editor) (1978), Ngo Thi Nham poetry collection, volume 1, Social Science Publishing House, Hanoi. (Cao Xuan Huy, Thạch Can (Chu bien) (1978), Tuyen tap tho van Ngo Thi Nham, quyen 1, Nxb Khoa học xa hoi, Ha Noi).

2. Tran Dình Huou (1998), Confucianism and Vietnamese literature in middle-class, Education Publishing House, Hanoi.(Tran Dinh Huou (1998), Nho giao va van hoc Viet Nam trung can dại, Nxb Giao dục, Ha Noi).

3. Le Van Tan (2013), Author of Vietnamese reclusive and middle-class grape houses, Social Science Publishing House, Hanoi. (Lê Văn Tan (2013), Tac gia nha nho an dat va van hoc trung dai Viet Nam, Nxb Khoa hoc xa hoi, Hà Nội).

4. Le Van Tan (2013), "The type of reclusive grape author in medieval literature in Vietnam", Journal of Literary Studies, No. 10. (Lê Văn Tấn (2013), "Loại hình tác giả nhà nho ẩn dật trong văn học trung đại Việt Nam”, Tạp chí Nghiên cứu văn học, số 10).

5. Le Van Tan (2014), "Identifying the type of idle author in medieval literature in Vietnam", Journal of Social Science Information, No. 11. (Lê Văn Tấn (2014), "Nhận diện loại hình tác giả nhàn tản trong văn học trung đại Việt Nam", Tạp chí Thông tin khoa học xã hội, số 11). 
6. Tran Nho Thin (2003), Vietnamese medieval literature from a cultural perspective, Education Publishing House, Hanoi. (Trần Nho Thìn (2003), Văn học trung đại Việt Nam duoói góc nhìn văn hóa, Nxb Giáo dục, Hà Nội).

7. Tran Ngoc Vuong (1995), Type of literary author study - Vietnamese amateur and literary grape house, Education Publishing House, Hanoi.(Trần Ngọc Vương (1995), Loại hình học tác giả văn học - nhà nho tài tử và văn học Việt Nam, Nxb Giáo dục, Hà Nội).

8. Tran Ngoc Vuong (1998), Vietnam Literature own line between common source, Education Publishing House, Hanoi.(Trần Ngọc Vương (1998), Văn học Việt Nam dòng riêng giũa nguồn chung, Nxb Giáo dục, Hà Nội). 